\title{
Research
}

\section{Conceptualizing and Operationalizing Social Resilience within Commercial Fisheries in Northern Australia}

\author{
$\underline{\text { Nadine A. Marshall }}^{1}$ and Paul A. Marshall ${ }^{2}$
}

\begin{abstract}
How can we tell whether resource-dependent people are socially resilient to institutional change? This question is becoming increasingly important as demand for natural resources escalates, requiring resource managers to implement policies that are increasingly restrictive on resource users. Yet policy changes are frequently made without a good understanding of the likely social and economic consequences. Knowledge of the resilience of resource users to changes in resource-use policies can assist in the design and implementation of policies that minimize the impacts on people while maximizing the sustainability of ecosystem goods and services. Despite the appeal of resilience as a framework for sustaining human-environment relations, there has been a distinct lack of explicit application of the concept by naturalresource managers. In response, we build on general resilience theory to develop a conceptual model of social resilience for resource-dependent users. We test and refine the operational virtues of the model using the commercial fishing industry in North Queensland. Detailed surveys of individual resource users provide data on historic response, expected well-being, and capacity as a basis for assessing resilience. We find that the response of fishers to generic yet anticipated change events is determined by four key characteristics: (1) perception of risk associated with change; (2) perception of the ability to plan, learn, and reorganize; (3) perception of the ability to cope; and (4) level of interest in change. These responses represent relative measures of the likely response of resource users to prospective changes in resource policy that affect the way in which the resource is used or accessed.
\end{abstract}

Key Words: social resilience; social adaptation; social impacts; institutional change; socio-ecological systems; integrated research; policy response; natural resource management; fishing; Australia

\section{INTRODUCTION}

Increases in the demand for natural resources and the impacts of a growing world population on the environment have meant that policies that regulate the use of, or access to, natural resources are increasing in number and in stringency (Holling and Meffe 1996, Caddy 1999, Ostrom et al. 1999, Lane and McDonald 2002). Invariably, the restrictions required to sustain the supply of ecosystem goods and services result in impacts on resource users (Machlis and Force 1988, Stedman 1999, Wingard 2000). Although these can have immediate and significant social and economic implications, resource policies that are implemented without due consideration of the social consequences also often generate conflict and lead to poor compliance (Sutinen 1998, Sutinen and Kuperan 1999, May 2004, Hiedanpaa 2005). This, in turn, undermines the effectiveness of the policies in achieving their original goal of resource sustainability (Maiolo et al. 1992, Roe 1996, Hampshire et al. 2004). Understanding the responses of resource users to planned changes in resource policy is central to effective management of natural resources.

A driving factor in the response of resource users is their resilience to policy change. The ability of resource users to cope with and adapt to changes in the rules that govern their access to natural resources will determine their willingness and capacity to comply and will determine, as well, the social and economic impacts of their response. Natural resource policies that take into account the resilience of resource users are likely to be much more effective at achieving resource sustainability, while also minimizing the social and economic impacts of these changes. However, because of the 
difficulties inherent in predicting and measuring responses of complex social-ecological systems (Scoones 1999, Davidson-Hunt and Berkes 2004), resource policies are frequently developed and applied without good a understanding of the likely consequences (Adger 2000, Wiber 2000, Berkes and Jolly 2001, Morrison et al. 2004). Emerging ideas and knowledge about resilience offer a framework in which many of these difficulties can be approached, encouraging progress toward the ultimate goal of sustainable natural resources and sustainable social and economic systems (Ludwig et al. 1997, Berkes and Folke 1998, Levin et al. 1998).

Resilience is the ability of socio-ecological systems to cope with and adapt to change (Folke et al. 2002). Resilient systems are adaptable, flexible, and prepared for change and uncertainty (Gunderson 1999, Hughes et al. 2005). Nonresilient systems, in contrast, are prone to irreversible or catastrophic change and are at risk of shifting into another, often undesirable, state governed by different rules and processes. Knowledge of the resilience of a system enables managers to foresee the likely consequences of external change events, such as new policies, and thus choose policy options that balance social and economic costs with resource sustainability goals. Resilience-based management also enables managers to choose the policy options that are least inclined to erode the resilience of the social-ecological system and thus least likely to compromise its ability to cope with and adapt to future change (Holling and Meffe 1996, Holling et al. 1998, Holling 2004). Managing for resilience is thus a means by which resource managers can design resource-protection strategies that minimize current socioeconomic impacts without unduly minimizing the system's ability to cope with future disruptions (natural or man made) (Lane and Stephenson 1997, Levin et al. 1998, Carpenter et al. 2001, Scheffer et al. 2001).

Despite the apparent appeal of resilience as a framework for sustaining human-environment relations and the theoretical advancements in the field (Holling 1973, Gunderson and Holling 2002, Olsson et al. 2004a), natural resource managers do not explicitly apply this concept very often (Adger 2000, Folke 2003, Colding et al. 2004, Olsson et al. 2005). Resilience is often complex, context specific, and highly dynamic, qualities that make it hard to develop general tools and methods of application (Berkes and Folke 1998, Walker et al. 2002, Kallstrom and Ljung 2005). Even in theory, the location of thresholds between desirable and undesirable states is difficult to measure and often subject to shift over time because of the complex and dynamic behavior of resource systems (Berkes and Jolly 2001). As a result, resilience has been difficult to define in operational terms, and its utility to practical management remains substantially underdeveloped (Olsson et al. 2004b, Walker and Meyers 2004).

In this paper we develop operational definitions for resilience within a primary resource industry and present a conceptual model aimed at assisting resource managers to practically incorporate resilience knowledge into policy development and implementation. We focus our study on the resilience of social elements of the system to assist managers to understand and predict the responses of resource users to policy change. We use the commercial fishing industry in the Great Barrier Reef (GBR) Marine Park, Australia, as a case study. Like other fisheries around the world, the sustainability of GBR fisheries is often the subject of scientific and public debate, driving increasingly restrictive policy revisions (Hanna 1996, McCay 1996, Bailey 1997). Recent increases in the total amount of "no-take" areas within the GBR Marine Park have lead to strident claims of social and economic hardship, with potentially large financial and political costs to the institutions responsible for approving and implementing the new policies (S. Howe, personal communication). These events have brought into sharp relief the need for tools to predict social and economic consequences of policy options as a means of minimizing unwanted or unpredictable costs of policy change in this natural resource setting.

Analysis of the commercial fishing industry in North Queensland illustrates the complexities of conceptualizing social resilience. When faced with a change in policy that restricts use or access to the fisheries resource, commercial fishers have many choices as to how they may respond. In one instance, a fisher may be able to incorporate the requirements of the policy change into his/her working life, continue to function as a fisher, and be recognized as resilient. In another instance, a fisher may decide that the ecological, social, or economic conditions within the existing system, or proposed system, have become untenable and that he would be better off leaving the industry (Walker and Meyers 2004). $\mathrm{He} / \mathrm{she}$ may still be demonstrating resilient properties at a societal level, i.e., social resilience, 
while not demonstrating resilience within the resource system, i.e., socio-ecological resilience. He has shifted from the fisheries resource system into the broader societal system. He has shown the capacity to reorganize and has undergone a social transformation (Holling 2004, Olsson et al. 2004a, Trosper 2003). A fisher who becomes a farmer as a result of a change in fisheries policy and continues to earn a similar income might perceive the state of not fishing as being equally desirable, especially if he is earning a comparable income and enjoying similar life-style rewards. If he is paying the same tax, for instance, as when he was a fisher, he is socially resilient; he is maintaining the same function at a societal level. This definition of social resilience refers to a seminal definition by Adger et al. (2002:358), who describe social resilience as "the ability of communities to absorb external changes and stresses while maintaining the sustainability of their livelihoods. Importantly, and in the third instance, some fishers remain within the commercial fishing industry after a policy change not because they are resilient, but because they lack other employment opportunities. Such fishers are socio-ecologically nonresilient and have entered into an undesirable state even though they appear to be maintaining their structure and function within the resource-extractive industry.

These scenarios emphasize the conceptual difficulties associated with the term "social resilience" compared with examining the ecological components of a system. We argue that to inform resource managers of the current state of the socioecological system and to make the concept operational, knowledge of the proximity of resource users to their "thresholds of coping" must be collected from people experiencing the event. This knowledge must be related to aspects of the level of well-being that resource users have in response to prospective policy change (Krannich and Greider 1984, Chambers 1989, Walker and Meyers 2004, Kallstrom and Ljung 2005). If fishers report a high level of well-being, they are demonstrating resilient properties and are expected to be socially resilient regardless of whether they remain within the industry or not. In this study we focus on the response of commercial fishers to nonspecific or generic changes in fisheries policy as an indicator of their likely resilience.

\section{METHODS}

To measure response to change, a list of statements about expected well-being, historic response, and capacity to adapt to nonspecific change was generated on the basis of the literature and a scoping study. The survey statements attempted to measure the level of well-being of commercial fishers, including their confidence in and concerns about coping with and adapting to changes in fisheries policy. Fishers were asked to self-assess their expected level of well-being in terms of acceptability, flexibility, other opportunities, and willingness to be creative and novel in their approach to adapting to the requirements of policy change. A scoping study was used to ensure that the scales were as representative of the constructs as possible. A list of items was pretested as part of a pilot study. Data were checked for skewness and kurtosis or normality, and questions were modified or omitted as necessary. Respondents were asked to rate their attitude to each of the final 17 statements using a four-point Likert scale.

The final version of the survey (Table 1) was administered to 100 commercial fishers in five coastal communities in North Queensland: Cooktown, Port Douglas, Innisfail, Townsville, and Bowen. These communities represented a span of population sizes, ranging from 1,800 for Cooktown to 91,000 for Townsville. Commercial fishers represented less than $2 \%$ of each community. Sampling was carried out by visiting each community and contacting as many commercial fishers as possible until 100 commercial fishers had participated in the research. The surveys were voluntary and received a $100 \%$ response rate. Between $46 \%$ and $68 \%$ of the commercial fishing industry within each community was sampled (Marshall 2006).

Only those statements that contributed to the internal consistency of the scale for social resilience, as described by a reliability analysis, were included (Carmines and Zeller 1979, Zeller and Carmines 1980, Spector 1992). A reliability analysis is based on a calculation of the correlation among statements using Cronbach's $\alpha \mathrm{a}$ (Chen and Popovich 2002). A Cronbach's $\alpha$ a of 0.7 or greater was accepted as indicating a reliable scale (Nunnally 1978, Sutton and Ditton 2001). 
Table 1. Descriptive statistics and reliability analysis for the response of the sample of commercial fishers to each survey item; $\alpha$ is Chronbach's $\alpha$.

\begin{tabular}{|c|c|c|c|c|}
\hline Survey items & Mean $^{\dagger}$ & $\begin{array}{l}\text { Standard de- } \\
\text { viation }\end{array}$ & $\begin{array}{l}\text { Item-total co- } \\
\text { rrelation }\end{array}$ & $\begin{array}{l}\alpha \text { if item } \\
\text { deleted }\end{array}$ \\
\hline I am confident that I could get work elsewhere if I needed to. & 1.98 & 1.06 & .46 & .653 \\
\hline I would be nervous trying something else. & 1.89 & .97 & .45 & .656 \\
\hline $\begin{array}{l}\text { I am more likely to adapt to change compared to other fishers I } \\
\text { know. }\end{array}$ & 2.68 & .90 & .47 & .656 \\
\hline I am confident things will turn out well regardless of changes. & 2.09 & 1.08 & .43 & .656 \\
\hline $\begin{array}{l}\text { I have many career options available to me if I decide to no } \\
\text { longer be a fisher. }\end{array}$ & 1.66 & .91 & .41 & .662 \\
\hline $\begin{array}{l}\text { Every time there is a new change I plan a way to make it work } \\
\text { for me. }\end{array}$ & 2.86 & .94 & .68 & .666 \\
\hline If there are any more changes I will not survive much longer. & 2.18 & 1.00 & .32 & .670 \\
\hline I can cope with small changes in industry. & 3.01 & .85 & -.05 & .676 \\
\hline I am too young to retire and too old to find work elsewhere. & 1.66 & .88 & .23 & .680 \\
\hline I have planned for my financial security. & 3.06 & .98 & .20 & .684 \\
\hline I am not competitive enough to survive much longer." & 2.86 & 1.15 & .13 & .684 \\
\hline I am interested in learning new skills outside of the industry. & 2.32 & 1.1 & .17 & .685 \\
\hline I would find it very difficult working for someone else. ${ }^{\S}$ & 1.89 & 1.02 & .56 & .685 \\
\hline Change is normal part of our everyday life. ${ }^{\S}$ & 2.85 & .84 & .28 & .686 \\
\hline $\begin{array}{l}\text { I would like to start up a business one day doing something } \\
\text { other than fishing. }{ }^{\S}\end{array}$ & 1.97 & .95 & .30 & .693 \\
\hline I believe that the future will look after itself. ${ }^{\S}$ & 1.64 & .85 & .02 & .700 \\
\hline $\begin{array}{l}\text { I am always thinking of new and better ways to improve my } \\
\text { fishing business. }\end{array}$ & 2.97 & .94 & .27 & .706 \\
\hline
\end{tabular}

${ }^{\dagger}$ Statements were measured on a 4-point scale: 1 = strongly disagree, 2 = disagree, $3=$ agree, $4=$ strongly agree.

¥The data for negatively worded statements were reversed prior to analysis.

${ }^{\S}$ The five statements that were removed from the scale were those with the largest Cronbach's $\alpha$ if deleted. 
To identify the underlying variables comprising the response to change and to reduce the complexity of factors to a more manageable number, a Principal Components Analysis (PCA) was used. A PCA is a statistical technique used to discover which statements form subsets that are relatively independent of one another. Statements that are correlated with one another but are largely independent of other responses are combined into factors (Zeller and Carmines 1980, Tabachnick and Fidell 1996). A PCA is based on the assumption that certain underlying factors, which are smaller in number than the original number of statements, are responsible for the co-variation among the responses. In this study, the data were rotated using an orthogonal rotation or varimax, which simplifies the factor structure by maximizing the variance of a column in the pattern matrix (Kim and Mueller 1978).

An important step in analyzing the results of a PCA is to ensure that each component identified is labeled as accurately as possible; this is necessary to accurately interpret the response of fishers to changes in policy. Each component was labeled on the basis of the statements comprising it. The validity of each interpretation was tested by correlating the factor scores with similar statements in the survey that were not intended to measure social resilience.

The validity of each interpretation was further examined using qualitative data. Qualitative interviews were undertaken during the same period as the quantitative surveys. The goal of this phase of the study was to gain as much interpretative information as possible to validate the results from the quantitative survey. Interviews usually lasted 2$3 \mathrm{hr}$, and every effort was made to approach each interview similarly and provide similar information to each fisher about the research. Commercial fishers were asked to describe their historic and expected response to policy change. Detailed notes were taken during each interview and were later edited as part of a research journal. Interview summaries for each of the 100 participants were constructed on the basis of the research journal. A content analysis was used to analyze the data from the interview summaries (Weber 1985, Stemler 2001). Keywords such as "risk," "confidence," "planning," "coping," and "interest" were used, with other keywords added as necessary. Meanings associated with each keyword were used to develop a picture of the range of responses to changes in fisheries policy and to describe how the quantitative results might be interpreted.

Issues of scale are critically important in examining the dynamics and adaptive capacity of socioecological systems. We concentrated on defining and assessing the response of individuals to policy change, because this scale is seldom addressed. Individual responses are important in driving and understanding resilience at higher scales (Meffe 2001, Adger et al. 2002, Manfredo and Dayer 2004). Data collected on individuals allow analysis of social resilience at higher levels of organization (families, communities, etc.), without masking some of the fundamental properties that may determine responses to policy change (Machlis et al. 1990, Freudenberg and Gramling 2002, Mascia et al. 2003, Trosper 2004). Our focus on individuals also increases the general applicability of results to other social-ecological systems (Smith 1995, Salz 1998, Smith et al. 2003, Bradley and Grainger 2004).

The mean age of the fishers in the study was 52 (born in 1953). On average, fishers entered the industry in their early twenties, had lived within their community for $23 \mathrm{yr}$, and had a family member, such as a father, brother, uncle, or grandfather, who also fished. The average fisher had completed a formal education to a mid-school level, and about half of the fishers in the sample had completed an apprenticeship. About $85 \%$ of fishers had worked in a different industry at some stage, although only $30 \%$ believed that they could ever gain employment again in that industry if the need arose (Marshall 2006).

\section{RESULTS}

\section{Defining social resilience}

Twelve statements in the survey to assess social resilience (Table 1) reliably assessed a commercial fisher's response to hypothetical policy change (Marshall 2006). Table 1 presents the descriptive statistics and the results of the reliability analysis for each of the 17 survey statements used to quantify social resilience. Table 1 also shows that, of the 17 statements, only 12 reliably contributed to the scale. These 12 statements formed the basis of the measure for social resilience in this study. 
The Principal Components Analysis revealed that the responses to the statements were best described by four factors. These factors represented $60.1 \%$ of the variance (Table 2).

The first component, representing $23.4 \%$ of the variance, consisted of statements relating to the perception of risk associated with absorbing and adapting to change. The statements made reference to the ability to secure work elsewhere if the need arose, as well as the ability to cope with small changes within the industry (Table 1). The second component, representing $18.6 \%$ of the variance, consisted of statements relating to the ability to plan, learn, and reorganize. The third component, representing $9.6 \%$ of the variance, consisted of statements relating to the ability to cope with change or the rate at which thresholds of coping are reached. The fourth and final component, representing 8.5\% of the variance, consisted of the single statement, reflecting the ability and interest of fishers to adapt to change by reinventing themselves. Results show that the relative contributions of survey items to the total variance are largely distributed among many different factors.

\section{Interpreting resilience components}

The information gained from semistructured qualitative interviews provided insights into the derived resilience components. Detailed discussions with interviewees helped to explain the basis of their responses and thus to further resolve the drivers of resilience among commercial fishers in the context of policy change. Qualitative data also confirmed the complexity of the response and provided some explanation as to why only $60 \%$ of the total variance in the sample could be explained by the four components. The considerations and issues revealed by qualitative surveys to be behind the four key resilience components are presented below.

\section{1) The perception of risk in approaching change}

Commercial fishers assessed their vulnerability to institutional or policy change on the basis of their financial situation, their ability to secure employment elsewhere, and their ability to remain competitive within the industry. Fishers with a larger financial buffer felt less vulnerable to policy change, as they believed that they could absorb the costs of change more easily and remain viable within the industry. For example, they could purchase bigger fishing vessels and better gear to enable them to travel farther in the event, for example, of closures to nearer fishing grounds or increased competition within remaining fishing grounds. Fishers who had developed transferable skills in another trade felt that they could cope if conditions became untenable within the industry by securing employment elsewhere. Many fishers, ver, felt that they lacked a financial buffer or the necessary skills to successfully see themselves through the transition to a new policy environment to successfully adapt to a new policy environment.

\section{2) The ability to plan, learn, and reorganize}

Fishers with well-developed business skills were more positive in their perception of their ability to plan and reorganize in the event of change. These fishers tended to be relatively new to the industry; they had thus already experienced a successful adaptation or transformation, had confidence in their ability to develop creative and novel solutions to deal with changing conditions, and were younger and more enthusiastic about remaining viable within the industry or setting up a business outside of the industry. Those who were less positive in their ability to plan, learn, and reorganize tended to be older fishers for whom the idea of reorganizing was "exhausting," were extremely attached to their occupation (for example, "I wouldn't swap my life for anything"), or who did not have the necessary skills to visualize options available to them (for example, "I have no idea what else I can do").

\section{3) Perception of the ability to cope with change}

Fishers perceived their proximity to their thresholds of coping in financial, emotional, and marital terms. Fishers in a better financial situation with regard to, e.g., debt repayments and number of assets, were more positive about their proximity to their thresholds. Fishers confident in their ability to be competitive or to adapt outside of the industry were also more positive. Fishers who had experienced marital distress as a result of previous change events tended to believe that their relationship would be unable to endure further change. Fishers who were particularly negative about their ability to cope with policy change were men in their early fifties. They believed that they were mostly unemployable but too young to retire or access superannuation or pension benefits, and they possessed too many assets to be eligible for other welfare benefits. 
Table 2. A Principal Components Analysis matrix of the responses of fishers to policy change. The first Principal Component (PC 1) represents statements related to the perception of risk associated with absorbing and adapting to change; these statements made reference to the ability to secure work elsewhere if the need arose, as well as the ability to cope with small changes within the industry. The second component consisted of statements related to the ability to plan, learn, and reorganize. The third component consisted of statements related to the ability to cope with change or the rate at which thresholds of coping are reached. The fourth and final component consisted of a single statement reflecting the ability and interest of fishers to adapt to change by reinventing themselves. Factor loading scores of less than 0.45 are not displayed.

\begin{tabular}{|c|c|}
\hline Survey items & $\begin{array}{c}\mathrm{PC} 1 \\
23.4 \%\end{array}$ \\
\hline I have many options available if I decide to no longer be a fisher. & 0.808 \\
\hline I am confident that I could get work elsewhere if I needed to. & 0.787 \\
\hline I am too young to retire and too old to find work elsewhere..$^{\dagger}$ & 0.625 \\
\hline I would be nervous trying something else..$^{\dagger}$ & 0.603 \\
\hline I can cope with small changes in industry. & -0.462 \\
\hline I have planned for my financial security. & \\
\hline Every time there is a change I plan a way to make it work for me. & \\
\hline I am more likely to adapt to change compared to other fishers. & \\
\hline
\end{tabular}

I do not think I am competitive enough to survive much longer. ${ }^{\dagger} \quad 0.682$

$\begin{array}{ll}\text { I am confident things will turn out well for me. } & 0.637\end{array}$

$\begin{array}{ll}\text { If there are any more changes I will not survive much longer. }{ }^{\dagger} & 0.547\end{array}$

I am interested in learning new skills outside of the industry. 0.936

${ }^{\dagger}$ The data for negatively worded statements were reversed prior to analysis.

\section{4) The level of interest in adapting to change}

Fishers who were more interested in adapting to policy change had fewer constraints. Constraints were discussed mostly in terms of family commitments, attachment to the occupation, and financial leeway. Divorced fishers in particular did not have the flexibility to search for income opportunities elsewhere because this meant that it would be even more difficult to spend time with their children. Grandparents tended to express similar concerns about maintaining relationships with their grandchildren. Fishers with a high level of attachment to the occupation were inflexible to other options. Fishers who were not in a strong financial position also believed that they could not afford the costs of change and thus showed less interest in adapting. 


\section{DISCUSSION}

As Carpenter and Brock (2004) noted, "many indicators, in many dimensions, are necessary to adequately represent resilience." This study has identified the key characteristics of individuals that determine their ability to cope and adapt to prospective changes in resource policy. Although social resilience is a complex and multidimensional concept, our results indicate that the source of resilience in commercial fishers confronted with policy change can be described by four derived characteristics: (1) the perception of risk associated with change; (2) the ability to plan, learn, and reorganize; (3) the perception of the ability to cope; and (4) the level of interest in change. These four characteristics can explain the variance within this study with more than $60 \%$ reliability. This model provides a standardized framework for defining and quantifying social resilience, at least for resource industries similar to the fishing industry in North Queensland.

General resilience theory describes a conceptual model for socio-ecological resilience based on three system characteristics: (1) the amount of disturbance a system can absorb and still retain the same structure and function, (2) the degree to which the system is capable of self-organization, and (3) the degree to which the system can build and increase the capacity for learning and adaptation (Holling 1973, Carpenter and Gunderson 2001, Folke et al. 2001). Three of the factors that describe the resilience of fishers to policy change in this study can be readily mapped against this generalized conceptual model.

The perception of the ability to cope with change, as characterised in our study, is analogous to the first defining attribute in general resilience theory: the amount of disturbance a system can absorb. In this study, the ability to cope, or the proximity to coping thresholds, was determined by asking fishers to evaluate their level of well-being in terms of financial and emotional stress, including their ability to secure alternative income. Much research has concentrated on the psychological effects of stress and change (e.g., Milbrath 1995, Saegert and Winkel 1990, Rickson et al. 1990), and these effects can be particularly important in natural resource settings. Smith et al. (2003), for example, in a study of the mental health of commercial fishers after the Florida Net Ban, demonstrated increases in levels of stress, depression, anxiety, and anger as a result of the policy changes. Stress, regardless of the way it manifests itself but as measured by those experiencing the event, can thus be a significant response to policy change. By assessing the perceptions of individuals about stress and their proximity to coping thresholds, researchers can gain an indication of the amount of disturbance the system can absorb before it begins to lose its defining structure and function.

The level of interest in change of the fishers in this study corresponds with the second defining attribute of resilience: the degree to which the system is capable of self-organization. In this study, the level of interest in adapting to the requirements of policy change is related to an individual's financial, social, and emotional flexibility. Several researchers discuss the importance of flexibility in the maintenance of resilience, and how flexibility can enable an individual or system to be resilient (Carpenter and Gunderson 2001, Shindler and Cheek 1999, Gunderson 1999). Loss of flexibility refers to the inability to take advantage of other options within the industry or community. It can be retarded by attitudinal constraints relating to family and financial commitments as well as through a lack of necessary or transferable skills (Gramling and Freudenberg 1992). An understanding of the capacity and interest of individuals in changing with circumstances can be used to assess the potential for self-organization.

We found that the ability of fishers to plan, learn, and reorganize was important in determining their resilience to policy change. This is consistent with the third defining attribute in general resilience theory: the ability to learn and reorganize (Folke et al. 2001). Researchers have previously found that the capacity to reorganize in the face of change is dependent on novelty, creativity, experimentation, learning, and planning (Harris et al. 1998, Colding et al. 2004, Olsson et al. 2004a). Our results support the generality of this relationship: fishers who prided themselves on developing new fishing methods or displayed adaptive business management skills tended to score more highly for this component of resilience. The importance of these characteristics has also been recognized in other studies, although mostly at larger scales of organization, such as community, organizational, and systemic levels (Hiedanpaa 2005, Carpenter and Gunderson 2001, Schefer et al. 2001). Our surveys identified substantial variation among fishers in their ability to plan for and adapt to change 
imposed by external forces, suggesting that measurements of these characteristics might be particularly useful in discriminating among individuals with different levels of resilience.

This study also identified a fourth factor that proved to be fundamental in determining the ability of fishers to cope and adapt to change: the perception of risk. Our results suggest that the way in which a fisher assesses the risks associated with proposed policy change is the major influence on the way he/ she responds. Despite its importance in our case study, the perception of risk associated with change is not readily mapped onto the general conceptual model of resilience in social-ecological systems. In part, this may be due to the fact that the perception of risk is a dimension of resilience unique to social systems. It may also relate to the predominance of post hoc analyses of responses to change events (Berkes and Jolly 2001). Perception of risk may have been revealed as important in our study because we examined social resilience to prospective policy change. Although the perception of risk has not previously been proposed as a predictor or descriptor of resilience within this context, recent studies have shown that vulnerability and resilience are closely linked (Adger 2006, Gallopin 2006, Vogel 2006). For example, practical adaptation initiatives tend to focus on risks that are already problematic (Smit and Wandel 2006).

Our findings about the role of risk perception in determining social resilience are also consistent with the findings of another study of resourcedependent people and their responses to change. Gramling and Freudenberg (1992) found that the way miners perceive change can significantly affect the way they initially cope and respond. Their study supports our observations that resource users assess the opportunities and threats associated with a proposed change even before the actual event begins to have any material effects on them. Further, the way resource users such as fishers evaluate these threats and opportunities is strongly influenced by their level of confidence in themselves and the institutions that govern their circumstances and prospects (Gramling and Freudenberg 1992). Confidence is a key quality because it determines the level of self-belief and self-reliance that a person has in approaching change (Kallstrom and Ljung 2005). However, confidence in itself is subject to change as a result of experiences with previous policy change. Fishers who have managed to incorporate previous change or adapt successfully are more likely to be confident in their ability to cope with future change and are thus more resilient. Knowledge of the confidence of resource users and their ability to perceive prospective change as an opportunity (or at least a manageable threat) provides resource managers and policy makers with an ability to assess social resilience. For this reason, we recommend that perception of risk be included as a key dimension in conceptual models of socialecological resilience.

An important tenet of this study was the importance of the assessment of the desirability of the end state or domain of attraction. Without this knowledge, it is not possible to accurately assess social resilience. It was argued earlier that this assessment had to be a self-assessment, because fishers with no resilience and no other options could still remain within the fishing industry after an institutional change. Only a self-assessment of well-being could differentiate between those fishers who remain with the industry because of their capacity to be resilient as opposed to those who remain because they have no other option. Fishers with high resilience may remain within the fishing industry after an institutional change because they (1) assess that they can manage the risks associated with the change and remain within the industry, (2) are confident that they have the skills and ability to incorporate the requirements of the change and reorganize themselves within the industry, (3) are far from their threshold of coping and can experiment with their options within the industry, or (4) have an interest in remaining within the industry but have the flexibility to leave should the need arise. Results also suggest that fishers who have high resilience can leave the industry as the result of institutional change to maintain their level of well-being because they (1) assess that the level of risk in leaving the industry is less than remaining within it, (2) are confident that they have the skills and ability to ensure a successful transition and can reorganize, (3) are far from their threshold of coping and can experiment with their options for the future, or (4) have an interest in leaving the industry and have the financial and familial flexibility to access other options.

Our study of commercial fishers in Queensland reveals that social resilience is a complex and multidimensional concept yet one that can be characterised by four measurable attributes. Three of these are captured within established conceptual models of social-ecological resilience, whereas the 
fourth is identified here for the first time. To the extent that the factors determining resilience in commercial fishers are common with those in other resource-dependent industries (e.g., Gramling and Freudenberg 1992, Lane and McDonald 2002, Kallstrom and Ljung 2005), this finding suggests that perception of risk should be included in future conceptual models of resilience, at least those applying to social systems subject to external change events.

Our results also provide insights to support the implementation of conceptual models of resilience. We find that there are identifiable and measurable characteristics of resource users that reliably determine their likely potential to cope with and adapt to prospective policy change. Through standard survey methods, resource managers and policy makers can evaluate the relative resilience of resource users to different policy options. By measuring the four key resilience attributes for resource users, i.e., the perception of risk associated with change; the ability to plan, learn, and reorganize; the perception of the ability to cope; and the level of interest in change, managers and policy makers can gauge the relative social consequences of different policy options. With this information, resource managers will have the capacity to reliably and defensibly design, select, and implement policies that minimize impacts on people while maximizing sustainability of ecosystem goods and services.

An ability to assess social resilience, and to understand its composite attributes at the level of individual resource users, also provides managers with the opportunity to enhance social resilience prior to implementing a policy change (Olsson et al. $2004 a, b$ ). To successfully navigate through policychange transitions, resource users require financial and emotional flexibility and a positive perception of policy change. An understanding of the influence of these qualities provides resource managers with a way to identify system properties that are amenable to management. Other influences will also be important in determining social resilience (Marshall et al. 2006). This knowledge, and that of the conditions under which social resilience can be influenced, can underpin progressive management approaches, such as sophisticated structured scenarios (Folke et al. 2005, Olsson et al. 2005) that are aimed at empowering stakeholders to contribute to more efficient and equitable resource protection. For example, managers could use the approaches developed in this study to identify resource users with a relatively low resilience to prospective policy change. Their ability to cope and adapt to a prospective policy change could be enhanced prior to its implementation through assistance in developing skills to plan and reorganize or in building capacity for alternative employment. Through improved models, the application of tools for measurement, and strategies for enhancing social resilience, communities, resource managers, and policy makers can realistically aim to minimize social and economic impacts while maximizing the environmental outcomes of policy change.

Responses to this article can be read online at:

http://www.ecologyandsociety.org/vol12/iss 1/art1/responses/

\section{Acknowledgments:}

We wish to thank Mark Fenton, Steve Sutton, Neil Adger, and Fikret Berkes for comments on an earlier version of the manuscript. We sincerely thank the 100 fishers and their families involved in the research. We gratefully acknowledge funding from the School of Tropical Environment Studies and Geography, James Cook University, Townsville, and the Cooperative Research Centre for ReefResearch, Townsville, Australia.

\section{LITERATURE CITED}

Adger,W. N. 2000. Social and ecological resilience: Are they related? Progress in Human Geography 24:347-364.

Adger, W. N. 2006. Vulnerability. Global Environmental Change 16(3):268-281.

Adger, W. N., P. M. Kelly, A. Winkels, L. Q. Huy, and C. Locke. 2002. Migration, remittances, livelihood trajectories, and social resilience. Ambio 31(4):358-366.

Bailey, C. 1997. Lessons from Indonesia's 1980 trawler ban. Marine Policy 21:225-235.

Berkes, F., and C. Folke. 1998. Linking social and ecological systems for resilience and sustainability. Pages 1-25 in F. Berkes and C. Folke, editors. 
Linking social and ecological systems: management practices and social mechanisms for building resilience. Cambridge University Press, Cambridge, UK.

Berkes, F., and D. Jolly. 2001. Adapting to climate change: social-ecological resilience in a Canadian western Artic community. Conservation Ecology 5 (2): 18. [online] URL: http://www.consecol.org/vol5/ iss $2 / \operatorname{art} 18$.

Bradley, D., and A. Grainger. 2004. Social resilience as a controlling influence on desertification in Senegal. Land Degradation and Development 15:451-470.

Caddy, J. F. 1999. Fisheries management in the twenty-first century: Will new paradigms apply? Reviews in Fish Biology and Fisheries 9:1-43.

Carmines, E. G., and R.A.Zeller. 1979. Reliability and validity assessment. Sage Publications, Beverly Hills, California, USA.

Carpenter, S., and L. Gunderson. 2001. Coping with collapse: ecological and social dynamics in ecosystem management. BioScience 51(6):451-457.

Carpenter, S., and W. A. Brock. 2004. Spatial complexity, resilience, and policy diversity: fishing on lake-rich landscapes. Ecology and Society 9(1): 8 [online] URL: www.ecologyandsociety.org/vol9/ iss1/art8.

Carpenter, S., B. Walker, J. Anderies, and N. Abel. 2001. From metaphor to measurement: resilience of what to what? Ecosystems 4:765-781.

Chambers, R. 1989. Editorial introduction: vulnerability, coping and policy. Institute of Development Studies Bulletin 20(2):1-7.

Chen, P. Y., and P. M. Popovich. 2002. Correlation: parametric and nonparametric measures. Sage Publications, Thousand Oaks, California, USA.

Colding, J., T. Elmqvist, and P. Olsson. 2004. Living with disturbance: building resilience in social-ecological systems. Pages 163-173 in F. Berkes, J. Colding, and C. Folke, editors. Navigating social-ecological systems: building resilience for complexity and change. Cambridge University Press, Cambridge, UK.
Davidson-Hunt, I. J., and F. Berkes. 2004. Nature and society through the lens of resilience: toward a human-in-ecosystem perspective. Pages 53-81 in F. Berkes, J. Colding, and C. Folke, editors. Navigating social-ecological systems: building resilience for complexity and change. Cambridge University Press, Cambridge, UK.

Folke, C. 2001. Social-ecological resilience and behavioral responses. Available online at: http://w ww.beijer.kva.se/publications/pdf-archive/Disc155. pdf.

Folke, C. 2003. Conservation, driving forces, and institutions. Ecological Applications 6:370-372.

Folke, C., J. Colding, and F. Berkes. 2003. Synthesis: building resilience and adaptive capacity in social-ecological systems. Pages 352-387 in F. Berkes, J. Colding, and C. Folke, editors. Navigating social-ecological systems: building resilience for complexity and change. Cambridge University Press, Cambridge, UK.

Folke, C., S. Carpenter, T. Elmqvist, L. Gunderson, C. S. Holling, and B. Walker. 2002. Resilience and sustainable development: building adaptive capacity in a world of transformations. Ambio 31(5):437-440.

Folke, C., T. Hahn, P. Olsson, and J. Norberg. 2005. Adaptive governance of social-ecological systems. Annual Review of Environment and Resources. 30(1):441-473.

Freudenberg, W. R., and R. Gramling. 2002. Scientific expertise and natural resource decisions: social science participation on interdisciplinary scientific committees. Social Science Quarterly 83:119-136.

Gallopin, G. C. 2006. Linkages between vulnerability, resilience, and adaptive capacity. Global Environmental Change 16(3):293-303.

Gramling, R., and W. R. Freudenberg. 1992. Opportunity-threat, development, and adaptation: toward a comprehensive framework for social impact assessment. Rural Sociology 57(2):216-234.

Gunderson, L. 1999. Resilience, flexibility, and adaptive management - antidotes for spurious certitude? Conservation Ecology 3(1): 7. [online] 
URL: http://www.consecol.org/vol3/iss1/art7.

Gunderson, L., and C.S. Holling. 2002. Panarchy: understanding transformations in human and natural systems. Island Press, Washington, D.C., USA.

Hampshire, K., S. Bell, and G. Wallace. 2004. "Real" poachers and predators: shades of meaning in local understanding of threats to fisheries. Society \& Natural Resources 17:305-318.

Hanna, S. 1996. Creating user-group vested interest in fishery management outcomes: a case study. Pages 391-400 in R. M. Meyer, C. Zhang, M. L. Windsor, B. J. McCay, L. J. Hushak, and R. M. Muth, editors. Fisheries resource utilization and policy: proceedings of the World Fisheries Congress. Science Publishers, Lebanon, New Hampshire, USA.

Harris, C. C., W. J. McLaughlin, and G. Brown. 1998. Rural communities in the interior Columbia basin: How resilient are they? Journal of Forestry 96(3):11-15.

Hiedanpaa, J. 2005. The edges of conflict and consensus: a case for creativity in regional forest policy in southwest Finland. Ecological Economics 56(4):485-498.

Holling, C. S. 1973. Resilience and stability of ecological systems. Annual Review in Ecology and Systematics 4:1-23.

Holling, C. S. 2004. From complex regions to complex worlds. Ecology and Society 9(1): 11. [online] URL: http://www.ecologyandsociety.org/vol9/ iss1/art11.

Holling, C. S., F. Berkes, and C. Folke. 1998. Science, sustainability, and resource management. Pages 342-362 in F. Berkes and C. Folke, editors. Linking social and ecological systems; management practices and social mechanisms for building resilience.Cambridge University Press, Cambridge, UK.

Holling, C. S., and G. K. Meffe. 1996. Command and control and the pathology of natural resource management. Conservation Biology 10:328-337.

Hughes, T. P., D. R. Bellwood, C. Folke, R. S. Steneck, and J. E. Wilson. 2005. New paradigms for supporting the resilience of marine ecosystems. Trends in Ecology \& Evolution 20(7):380-386.

Kallstrom, H. N., and M. Ljung. 2005. Social sustainability and collaborative learning. Ambio 34:376-382.

Kim, J.-O., and C. W. Mueller. 1978. Introduction to factor analysis: what it is and how to do it. Quantitative applications in the social sciences. Sage University Papers Series 07-013. Sage Publications, Newbury Park, California, USA.

Lane, D. E., and R. L. Stephenson. 1997. Fisheries management science: integrating the roles of science, economics, sociology and politics in effective fisheries management. Pages 177-182 in D. A. Hancock, D. C. Smith, A. Grant, and J. P. Beumer, editors. Developing and sustaining world fisheries resources: the state of science and management. Commonwealth Scientific and Industrial Research Prganization, Collingwood, Australia.

Lane, M. B., and G. T. McDonald. 2002. Crisis, change, and institutions in forest management: the wet tropics of northeastern Australia. Journal of Rural Studies 18:245-256.

Levin, S., S. Barrett, S. Aniyar, W. Baumol, C. Bliss, B. Bolin, P. Dasgupta, P. R. Ehrich, C. Folke, I. Gren, C. S. Holling, A. Jansson, B. Jansson, K. Maler, D. Martin, C. Perrings, and E. Sheshinski. 1998. Resilience in natural and socioeconomic systems. Environment and Development Economics 3:222-235.

Likert, R. 1932. A technique for the measurement of attitude. Archives of Psychology 22:32-42.

Ludwig, D., B. Walker, and C. S. Holling. 1997. Sustainability, stability, and resilience. Conservation Ecology 11(1): 7. [online] URL: http://www.consec ol.org/vol1/iss1/art7.

Machlis, G. E., and J. E. Force. 1988. Community stability and timber-dependent communities. Rural Sociology 53:220-234.

Machlis, G. E., J. E. Force, and R. G. Balice. 1990. Timber, minerals, and social change: an exploratory test of two resource-dependent communities. Rural Sociology 55:411-424. 
Maiolo, J. R., J. Johnson, and D. Griffith. 1992. Applications of social science theory to fisheries management: three examples. Society and Natural Resources 5:391-407.

Manfredo, M. J., and A. A. Dayer. 2004. Concepts for exploring the social aspects of human-wildlife conflict in a global context. Human Dimensions of Wildlife 9:317-328.

Marshall, N. A. 2006. A conceptual and operational understanding of social resilience in a primary resource industry -insights for optimizing social and environmental outcomes in the management of Queensland's commercial fishing industry. Dissertation. School of Tropical Environment Studies and Geography, James Cook University, Townsville, Australia.

Marshall, N. A., D. M. Fenton, P. A. Marshall, and S. Sutton. 2006. How resource-dependency can influence social resilience within a primary resource industry. Rural Sociology 71, in press.

Mascia, M. B., J. P. Brosius, T. A. Dobson, B. C. Forbes, L. S. Horowitz, M. A. McKean, and N. J. Turner. 2003. Conservation and the social sciences. Conservation Biology 17:649-650.

May, P. J. 2004. Compliance motivations: affirmative and negative bases. Law and Society Review 38:41-45.

McCay, B. J. 1996. Participation of fishers in fisheries management. Pages 60-75 in R. M. Meyer, C. Zhang, M. L. Windsor, B. J. McCay, L. J. Husgak, and R. M. Muth, editors. Fisheries resource utilization and policy: proceedings of the World Fisheries Congress. Science Publishers, Lebanon, New Hampshire, USA.

Meffe, G. K. 2001. Crisis in a crisis discipline. Conservation Biology 15:303.

Milbrath, L. W. 1995. Psychological, cultural, and informational barriers to sustainability. Journal of Social Issues 51(4):101.

Morrison, T.H., G. T. McDonald, and M. B. Lane. 2004. Integrating natural resource management for better environmental outcomes. Australian Geographer 35:243-258.

Nunnally, J. C. 1978. Psychometric theory. Second edition. McGraw-Hill, New York, New York, USA.

Olsson, P., C. Folke, and F. Berkes. 2004a. Adaptive comanagement for building resilience in social-ecological systems. Environmental Management 34:75-90.

Olsson, P., C. Folke, and T. Hahn. 2004b. Socialecological transformation for ecosystem management: the development of adaptive co-management of a wetland in southern Sweden. Ecology and Society 9 (4): 2. [online] URL: http://www.ecologyandsociety. org/vol9/iss4/art2.

Olsson, P., S. Carpenter, L. Gunderson, P. Ryan, L. Lebel, C. Folke, and C. S. Holling. 2005. Shooting the rapids: navigating transitions to adaptive ecosystem governance. Ecology and Society 11(1): 18. [online] URL: http://www.ecolog yandsociety.org/vol11/iss1/art18.

Ostrom, E., J. Burger, C. B. Field, R. B. Norgaard, and D. Policansky. 1999. Revisiting the commons: local lessons, global challenges. Science 284:278-282.

Rickson, R. E., J. S. Western, and R. J. Burdge. 1990. Social impact assessment: knowledge and development. Environmental Impact Assessment Review 10:1-10.

Roe, E. 1996. Why ecosystem management can't work without social science: an example from the California northern spotted owl controversy. Environmental Management 20:667-674.

Saegert, S., and G. H. Winkel. 1990. Environmental psychology. Annual Review of Psychology 41:441-477.

Salz, R. J. 1998. Social justice and the Florida net ban controversy. Human Dimensions Research Unit, Department of Natural Resources Conservation, Amherst, Massachusetts, USA.

Scheffer, M., S. Carpenter, J. A. Foley, C. Folke, and B. Walker. 2001. Catastrophic shifts in ecosystems. Nature 413:591-596.

Scoones, I. 1999. New ecology and the social sciences: what prospects for a fruitful engagement? Annual Review of Anthropology 28:479-507.

Shindler, B., and K. A. Cheek. 1999. Integrating 
citizens in adaptive management: a propositional analysis. Conservation Ecology 3(1): 9. [online] URL: http://www.consecol.org/vol3/iss 1/art9.

Smit, B., and J. Wandel. 2006. Adaptation, adaptive capacity and vulnerability. Global Environmental Change 16:282-292.

Smith, S. 1995. Social implications of changes in fisheries regulations for commercial fishing families. Fisheries 20:24-26.

Smith, S., S. J. Jacob, M. Jepson, and G. Israel. 2003. After the Florida net ban: the impacts on commercial fishing families. Society and Natural Resources 16:39-59.

Spector, P. E. 1992. Summated rating scale construction: an introduction. Quantitative applications in the social sciences. Sage University Papers Series 07-82. Sage Publications, Newbury Park, California, USA.

Stedman, R. C. 1999. Sense of place as an indicator of community sustainability. Forestry Chronicle 75:765-770.

Stemler, S. 2001. An overview of content analysis. PracticalAssessment, Research \& Evaluation 7: 17.

Sutinen, J. G. 1998. Blue water crime: deterrence, legitimacy, and compliance in fisheries. Law and Society Review 32:309-313.

Sutinen, J. G., and K. Kuperan. 1999. A socioeconomic theory of regulatory compliance. International Journal of Social Economics 26:174-193.

Sutton, S. G., and R. B. Ditton. 2001. Understanding catch-and-release behavior among U.S. Atlantic bluefin tuna anglers. Human Dimensions of Wildlife 6:49-66.

Tabachnick, B. G., and L. S. Fidell. 1996. Using multivariate statistics. Third edition. HarperCollins, New York, New York, USA.

Trosper, R. L. 2003. Resilience in precontact Pacific Northwest social ecological systems. Conservation Ecology 7(3): 6. [online] URL: http:/ /www.consecol.org/vol7/iss3/art6.

Trosper, R. L. 2004. Policy transformations in the US forest sector, 1970-2000: implications for sustainable use and resilience. Pages 328-351 in F. Berkes, J. Colding, and C. Folke, editors. Navigating social-ecological systems: building resilience for complexity and change. Cambridge University Press, Cambridge, UK.

Vogel, C. 2006. Forward: resilience, vulnerability and adaptation: a cross-cutting theme of the international dimensions program on global environmental change. Global Environmental Change 16(3):235-236.

Walker, B., S. Carpenter, J. Anderies, N. Abel, G. S. Cumming, M. Janssen, L. Levbel, J. Norberg, G.D.Peterson, and R.Pritchard. 2002. Resilience management in social-ecological systems: a working hypothesis for a participatory approach. Conservation Ecology 6(1): 14. [online] URL: http ://www.consecol.org/vol6/iss1/art14.

Walker, B., and J. A. Meyers 2004. Thresholds in ecological and social-ecological systems. Ecology and Society 9(2): 3. [online] URL: http://www.ecol ogyandsociety.org/vol9/iss2/art3.

Weber, R. P. 1985. Basic content analysis. Sage Publications, Beverley Hills, California, USA.

Wiber, M. G. 2000. Fishing rights as an example of the economic rhetoric of privatization calling for an implicated economics. Canadian Review of Sociology and Anthropology 37:267-288.

Wingard, J. D. 2000. Community transferable quotas: internalizing externalities and minimizing social impacts of fisheries management. Human Organization 59:48-57.

Zeller, D., and E. G. Carmines. 1980. Measurement in the social sciences. Cambridge University Press, London, UK. 